\title{
Applying the Concept of Social Corporate Responsibility to Ensure the Stability of Educational Activities
}

\author{
Kremleva O.K. \\ Saint Petersburg State University of Economics, \\ Saint Petersburg, Russia, \\ okremlev@mail.ru \\ Belyaeva T.P. \\ Saint Petersburg State University of Economics, \\ Saint Petersburg, Russia
}

\author{
Mjuller N.V. \\ Saint Petersburg State Economic University, \\ Saint Petersburg, Russia \\ Glushachenko S.B. \\ Russian State Pedagogical University \\ named after A.I. Herzen, \\ Saint Petersburg, Russia,
}

\author{
Kovaleva G.V. \\ Saint Petersburg State University of Industrial Technologies and Design, \\ Saint Petersburg, Russia
}

\begin{abstract}
The article analyses thoroughly the educational legal relationship. The legal nature of its implementation is deeply studied through defining the object, the subject composition, the legal status of the educational organization, the hierarchy of state authorities that manage educational activities, the goals of managing educational activities by the authorities. The authors come to the conclusion that educational legal relations present a triune process - organizing, implementing and controlling the educational activities process. The authors argue that the subject of educational legal relations is educational activity, i.e. a socially significant activity aimed at students' acquisition and development of knowledge, skills, and abilities during the educational process performed by teachers. It is noted that social responsibility is a form of practical implementation of the concept of sustainable development, ensuring its implementation in educational relations. The article suggests revising the role of trade unions and self-regulatory organizations in the implementation of the concept of socially responsible behavior in the educational sphere. The directions of application of the norms of educational legislation and local regulation in relation to teachers and employees of educational organizations in the following areas are discussed: development of forms of joint participation of educational organizations employees through the trade unions representation; control over the content and execution of the employment contracts terms.
\end{abstract}

Keywords-legal nature of educational relations, legal status of educational organizations, object, self-regulatory organizations, subject composition, the concept of social responsibility, trade unions

\section{INTRODUCTION}

The right to education as a fundamental human right has been thoroughly discussed in contemporary Russian research literature. Most of the authors spoke about the legal nature of education and educational relations.

A fundamental contribution to the national concept of the legal nature of education in the post-Soviet period was made by Prof. V.M. Syrykh, who qualified educational law as an independent complex branch of law [1]. At the same time, this concept is also criticized by some Russian scientists [2].

The discussion about the legal nature of educational relations, especially in terms of criticism of their qualification as a process of paid services, is practically over [3], but so far it has not led to any practically useful results. Teaching students in basic educational programs on a contract and budgetary basis is organized in general runs and groups; additional educational programs, respectively, are organized on demand for a set fee. The fact of payment does not at all guarantee the granted certification to the student, since, regardless of the type of financing the education, the recognition of learning outcomes testifies to the public credibility of qualifications and scope and becomes:

1) the student's goal in obtaining education;

2) the content of the educational institution's activity;

3) socially significant function of education which ensures the continuity of generations in the labor division and coordination. 
If compared to all other types of human activity, the educational activity peculiarity is that education extends to all spheres of life, continues throughout the entire life span and determines the life quality of both the person acquiring education and the entire society. It is the goal, content, and social significance of the function of education that determine its role in society and define the public-law nature of education as the main one.

\section{RESEARCH PROBLEM}

The discussion about the legal nature of educational relations should continue due to the fact that the problem solution is the key for the development of an effective legal regulation of educational activities $[4,5]$. This problem, being basic for the solution of all other issues of legal support in the field of education, requires revision, especially today, when knowledge has become one of the most important factors in the economic development of any country in the world because of its direct correlation with labor productivity [6].

In the era of the COVID-19 pandemic, finding new ways to achieve social stability in society has become relevant. Obviously, the restrictions imposed by states in the fight against the pandemic have significantly influenced the economic, organizational, managerial and other aspects of the implementation of educational activities and, accordingly, the stability of national educational systems and their continuity. The solution to this issue is extremely important within the framework of such a fundamental social institution as education, which performs a socially significant function, since its insufficiently effective regulation will negatively affect the stability of all the most important social institutions [7].

In the situation of the global fight against the pandemic, the sustainable development goals set by the world community have acquired the definite meaning for all humanity without exception. A successful implementation of the sustainable development agenda is impossible without setting at the global, regional and local levels partnerships between governments, the private sector and civil society that should be built on principles and values, on a common vision and common goals, and should be focused on meeting the interests of humanity and the planet.

Currently, two trends are clearly visible in Russian legal science: globalization and specialization. The globalization trend is determined by the processes taking place in the world economy and legal order, namely, the production enlargement and division of labor, an increase in the share of transnational business. The globalization component of the development of national educational law is expressed in the borrowing and adaptation of foreign institutions, the development of mechanisms for responding to the "challenges of the time". The flip side of the globalization trend is specialization, which is an independent legal phenomenon.

In the field of law serving educational activities, globalization and specialization are carried out as parallel processes, but within them institutional revision is required. There is the need for further research on both public law and civil law types of responsibility in the field of educational activity, including the limits of responsibility, the specifics of its origin and termination [8]. This thesis fully refers to social responsibility as the most important component that determines the legal nature of educational activities.

Social responsibility is a form of practical implementation of sustainable development concept. There is clearly a tendency of forming, firstly, a system of national and supranational regulation, secondly, standard local regulation, and thirdly, the social focus of corporate regulation. All of the above has brought to life the new revision of various legal institutions content. Until now, educational activity has not been considered from the point of view of regulating its social responsibility; it has been completely neglected by legists, while, undoubtedly, it requires legalization. The aforementioned ideas are confirmed by the fact that almost all countries of the world adopt socially responsible behavior codes, provide state support for their development, and stimulate self-regulatory organizations to follow this direction. In a number of countries, there is a unification of the regulation of socially responsible behavior; the accession to standard, recommended and similar regional codes is being carried out. In addition, there is a unification of requirements for monitoring compliance with social responsibility norms and the widespread implementation of such control.

In addition, corporate social responsibility is the most important bridge not only between business and society, but also between educational organizations and society, “... a means of informing corporations and government bodies about the value and importance of social responsibility to bridge the gap between the privileged and disadvantaged sectors of society" [9].

In the context of the problems of determining the legal nature of educational legal relations and the implementation of social responsibility in educational activities, it is important to identify the most important participants in the formation and control of the social policy of educational organizations in conditions of significant social instability.

\section{RESEARCH QUESTIONS}

The problem statement determines the research questions that we pose for resolution in the framework of the study.

3.1. Definition of the legal nature of the educational legal relationship in regards to its object, subject composition, the legal nature of its implementation, the legal status of the educational organization as the main subject of legal relationship, the main goal of the educational process leadership.

3.2. The possibility of applying the well-known concept of socially responsible behavior to the educational process, taking into account the legal nature of educational legal relationship in order to solve the problem of stability of educational activities, including its coordination.

3.3. Identification of the role of trade unions and selfregulatory organizations in the implementation of socially responsible behavior concept in the educational sphere.

\section{RESEARCH PURPOSE}

The given research is carried out to solve various problems of ensuring the stability of educational activities using the concept of socially responsible behavior during the educational process. 


\section{DisCUSSION AND RESUlTS}

The object of the educational legal relationship is constantly being discussed in the research literature due to its importance. We believe that the object of educational legal relations - the implementation of educational activities per se and the types of activities that provide it - is a process that, in accordance with the established conditions and the results achieved by students, allows talking about their acquisition of knowledge, skills and abilities in a certain combination.

Revealing the subject composition of educational legal relations, one cannot avoid the obvious conclusion that students are always citizens (individuals). This statement fully applies to corporate training, where despite the fact that the educational process is carried out according to the instructions and in the interests of the employer, it is the employees who acquire new competencies; as a result of professional development the members of one professional community generate a synergistic effect of the educational process efficiency.

In this regard, we admit that we do not support the concept of having an authorized and obligated party to the object of the legal relationship, since even if the training takes place on a commercial basis, the legal nature of its implementation is not covered by the structure of the obligatory civil law relationship.

As for commercial and non-commercial principles of organizing and carrying out educational activities, we argue that the variety of opportunities for access to education corresponds to the state-political structure at a certain stage of the socio-economic formation. The wide access to education, as well as the possible choice of compensation for the costs of obtaining it, testifies to the summative development of society. Therefore, it is impossible to ignore the presence of the infrastructure of education and related activities, where, undoubtedly, private law methods of regulation are applied within the limits that do not contradict the socially significant function of education. For example, paying for additional educational services by lagging students, organizing preparatory courses for applicants, paying for accommodation in a student dormitory are compensated contractual relations; however, they are interconnected with the main educational process therefore, they are regulated by educational legislation, including rates and tariffs.

The above allows estimating the special importance of understanding the legal status of an educational organization a legal entity, the main activity of which is the implementation of the educational process. This organization operates in the education system, that is, the system of subordination to the authorized bodies of state power that regulate the goals, objectives and results of certain types and levels of education, control their achievement while ensuring socially significant functions.

The hierarchy of bodies in charge of managing educational activities is established by the political will of the state and is consolidated normatively, through the transfer of some functions of managing educational activities to self-regulatory and public organizations. Traditionally, the functions of educational activities leadership are performed by government officials as the administrative apparatus of the ministry or its analogue is built. However, in various legal systems, the effectiveness of performing educational organizations leadership functions by such institutions as boards of trustees in the UK and the USA in relation to some educational organizations, by the Council of Rectors in relation to all educational organizations of vocational education in Germany, as well as the effectiveness of other forms and their combinations has been proven.

The main goal of the managing educational activities by public authorities and local governments is to ensure the implementation of constitutional guarantees for the protection of the life and health of students and employees of educational organizations, to provide free access to quality education, which is achieved through licensing of educational activities and accreditation of educational organizations.

Economic and legal studies mark the positive impact of corporate social responsibility on the financial condition of corporations; it is also applicable to educational organizations, although they pursue socially significant goals in the first place, their activities are impossible without monetizing its results. In particular, scientists note that “... improvement in environmental and social performance does lead to higher levels of financial performance" [10]. However, this position is controversial since it is difficult to speak of an unconditional positive relationship between increased attention to compliance with social responsibility standards and an increase in the financial performance of a corporation due to a number of factors which, on the contrary, lead to a decrease in such indicators, for example, as a result of the loss of customers due to the price rise caused by the increased production costs when environmentally friendly materials are used, etc. Despite this, "the responsiveness of companies in relation to numerous stakeholders is consistent with their interests - this does not promise huge profits, but will protect against sharp recessions" [10]. Education covers the training of specialists for all types of economic activity and, therefore, meets with all the numerous regulatory provisions; however, there are very specific requirements for educational activities, in particular, in regards to publications [11]. Nevertheless, even in this case, uniform patterns are noted: for ensuring educational activities, the normative consolidation of the need for socially responsible behavior represents a large reserve for self-regulation of all categories of subjects through the regulated imposing of social obligations on them.

Numerous international standards in the field of corporate social responsibility (hereinafter - CSR) streamline the control of the conduct and evaluation of activities aimed at the formation of socially responsible behavior, ensuring a high degree of information disclosure. Among other things, this practice helps to minimize the risks of organizations, including ecological ones [12]

Analysis of the above trends allows identifying the main CSR trends in education:

- support and respect for international human rights standards;

- inadmissibility of violation of human rights;

- occupational safety and health;

- environmental protection;

- anti-corruption. 
The practice of introducing socially responsible behavior as a form of implementing the concept of sustainable development will allow subjects of educational activity to:

- preventively form ideas about the intentions of interested parties regarding the content of educational activities;

- improve and promote the development strategy of the educational organization;

- provide feedback with employers, graduates, applicants, etc.;

- carry out long-term management of non-financial risks;

- form a business reputation;

- improve the forms and methods of organization management, including decision-making, increasing labor productivity and the competitiveness of educational activities results.

In the Russian Federation, the establishment of socially responsible behavior in the field of education has a huge potential both among public and private educational institutions and organizations. Along with that, a number of researchers believe that employees are the key stakeholders in the organization; therefore, the organization should participate in meaningful CSR activities. In particular, the interests of employees may constitute legal requirements, for example, "the fulfillment of the terms of the employment contract, as well as moral requirements, in particular, the ability of employees to express their opinion, or fair attitude of the organization towards employees" [13].

Since employees are often unable to ensure that the organization takes into account the above requirements on an individual basis, it is necessary to say about the modern role in the implementation of the concept of socially responsible behavior in the educational sphere of collective subjects, including trade unions and self-regulatory organizations. Trade unions and self-regulatory organizations are important participants in the development and control of the social policy of educational organizations due to the following factors:

- the ability to influence the activities of educational organizations by virtue of the law, i.e. through the availability of a proper legal personality secured by the requirements of labor legislation;

- the ability to be an effective participant in legal relations in the field of social responsibility (having both independence and interest), i.e. balance of motivations;

- possession of information about the problems of social responsibility and socially responsible behavior, as well as the best practice of their implementation, in other words, awareness;

- experience of participation in situations of conflict labor relations, professionalism.

A significant factor in the development of the CSR institution in the educational sphere is the media and the social networks coverage of the CSR activities of educational organizations [14]. At the same time, educational organizations should regularly publish CSR reports using information technologies, so that stakeholders can assess how companies comply with CSR obligations, these reports will show that it is important for an organization to take into account the interests of all stakeholders [15]. This practice is especially relevant against the background of the digital transformation of the higher education system in Russia, which strives to create a developed personality, a rationally thinking and quickly adaptable professional who is ready to live in the post-industrial era [16]

The function of protecting the interests of workers and employees has traditionally been carried out by trade unions, forged in the crucible of the struggle for the observance of labor rights. In the Soviet Union, and then in the Russian Federation, their legal status was directly enshrined in the Labor Code of USSR, and then the Labor Code of RF. Currently, trade unions in the field of education are able to open a new page of the two-aspect application of legislation and local regulation in relation to teachers and employees of educational organizations in the following areas:

1. development of forms of joint participation of educational organizations employees through the trade unions representation (ownership of stocks and shares; participation in supervisory boards);

2. control over the content and implementation of employment contract terms.

\section{SUMMARY OF THE FINDINGS}

6.1. Considering the high degree of complexity of educational relations, we summarize our findings:

6.1.1. Educational legal relations form a triune process the organization, implementation, and control of the process of educational activities implementation.

6.1.2. The subject of educational legal relations is educational activity, i.e. socially significant activity for the acquisition and improvement of students' knowledge, skills, and abilities in the process of their training by teachers

6.1.3. The legal nature of educational legal relations is public law; the relations that ensure the implementation of educational relations in a not prohibited scope have private law nature.

6.2. Summing up the research on the new for educational relations problems of socially responsible behavior and in view of the objectively established economic situation, it should be strongly recommended to develop educational legislation for stimulating:

6.2.1. implementation of social responsibility standards by educational organizations;

6.2.2. intensification of the activities of educators' trade unions, as well as self-regulating educational organizations, aimed at protection and involvement of their members in ensuring social protection and income growth for educators, while adopting the standards of social partnership.

\section{CONCLUSION}

This research shows that:

7.1. Taking into account the legal nature of educational relations, the concept of social responsibility can be 
effectively applied and evolved in solving numerous problems of ensuring the stability of educational activities.

7.2. Trade unions and self-regulatory organizations in the field of education are entitled to activate their potential, firstly, through the development of forms of joint participation of educational organizations employees through representation of the interests of educational relations participants; secondly, by participating in the working out recommendations for entering the civil and labor contracts, as well as for control over the content and implementation of civil and labor contracts.

\section{References}

[1] V.M. Syrykh, Introduction to the theory of educational law [Vvedeniye v teoriyu obrazovatel'nogo prava], Moscow: Gotika. 2002. (In Russ.)

[2] Education Law in Russia. The Yearbook of Education Law, Ohio: Dayton University, 2012.

[3] V.M. Syrykh, Educational services and educational legal relations: controversial views and actual content [Obrazovatel'nyye uslugi i obrazovatel'nyye pravootnosheniya: diskussionnyye vzglyady i deystvitel'noye soderzhaniye], Journal of Russian Law, 2010, vol. 4, pp. 69-79. (In Russ.).

[4] M.G. Averkin, N.V. Sorokina, and M.S. Mikhaylov, Interaction of subjects of the labor market and educational services: domestic and foreign experience [Vzaimodeystviye subjektov rynka truda obrazovatel'nykh uslug: otechestvennyy i zarubezhnyy opyt], Moscow: Akad. truda i sotsial'nykh otnosheniy, 2015. (In Russ.).

[5] T.M. Apostolova, A.V. Polovnikova, and S.S. Savva, Right to education in the Russian Federation [Pravo na obrazovaniye $\mathrm{v}$ Rossiyskoy Federatsii], Moscow: Knigodel, 2015. (In Russ.).

[6] L. Amaghionyeodiwe, and T. Osinubi, "The Development Impact of Higher Education in Nigeria", International Journal of Sustainable Development, 2012, vol. 4(9), pp. 85-120. Retrieved from https://ssrn.com/abstract=2132032

[7] T.V. Ryabko, and L.V. Shmel'kova, Additional professional education: on legislative and methodological support [Dopolnitel'noye professional'noye obrazovaniye: o zakonodatel'nom i metodicheskom obespechenii], Yaroslavl': Izd-vo Akademii Pastukhova, 2015. (In Russ.).

[8] V.V. Kvanina, Higher educational institution as a subject of law: problems of private and public law [Vyssheye uchebnoye zavedeniye kak subjekt prava: problemy chastnogo i publichnogo prava]. Chelyabinsk: YuUrGU, 2004. (In Russ.)

[9] Dr. Ramakrishnan, "Significant Changes in the Business in the Last 30 Years Due to Corporate Social Responsibility", DSA Corporate Social Responsibility Study Group at the Magdalene College, Cambridge University UK, 2008. Retrieved from http://dx.doi.org/10.2139/ssrn.1751602

[10] G. Serafeim, The Role of the Corporation in Society: An Alternative View and Opportunities for Future Research, 2013. DOI http://dx.doi.org/10.2139/ssrn.2270579

[11] O.A. Fikhtner, O.E. Vanyushkina, and G.V. Lebedeva, "Project Management Of Publication Activity At The Modern University", European Proceedings of Social and Behavioural Sciences, 2019, vol. 75, pp. 608-618. DOI: 10.15405/epsbs.2019.12.05.75

[12] V.V. Kvanina, and T.I. Makarova, "Public and private legal means of minimizing environmental risks: theoretical and instrumental analysis", Tomsk State University Journal of Law, 2020, vol. 36, pp.174-188.

[13] P. Jarkovská, M. Jarkovská, “A Contemporary Approach to Managing Social Responsibility in Relation to Employees as Perceived in Academic Papers", Journal on Efficiency and Responsibility in Education and Science, 2020, vol. 13(3), pp. 101-112. DOI: http://dx.doi.org/10.7160/eriesj.2020.130301

[14] L.M. Gomez, B. Morales, L. Vargas-Preciado, and R.C. Moure, "Are Stakeholders Engaged About Corporate Social Responsibility? Representations of CSR in the Puerto Rican Media Industry", in Proceedings of 11th International Conference on Corporate Social Responsibility, 2012. Retrieved from https://ssrn.com/abstract=2275709

[15] R. Safarzad, E. Farahnaki, and M. Farahbakhsh, Corporate Social Responsibility, Theories and Models, 2016. Retrieved from https://ssrn.com/abstract=2834200

[16] A. Vetkina, T. Kudryashova, O. Fikhtner, V. Trifonov, and E. Zhukova, "The Innovative Potential of Digital Transformation of the Russian Higher Education System: Trends of the Competence Approach", in Proceedings of Conference on International Conference on the Theory and Practice of Personality Formation in Modern Society, 2018. DOI https://doi.org/10.2991/ictppfms-18.2018.35 